\title{
Acute Pulmonary Histoplasmosis Outbreak in A Documentary Film Crew Travelling from Guatemala to Australia
}

\author{
Stephen Muhi *, Amy Crowe and John Daffy \\ St Vincent's Pathology, St Vincent's Hospital (Melbourne), Victoria 3065, Australia; \\ Amy.Crowe@svha.org.au (A.C.); john.daffy@svha.org.au (J.D.) \\ * Correspondence: steve.muhi@gmail.com
}

Received: 16 January 2019; Accepted: 31 January 2019; Published: 1 February 2019

check for updates

\begin{abstract}
Histoplasma capsulatum is an endemic mycosis with a widespread distribution, although it is infrequently reported in travellers. In April 2018, five television crew members developed an acute febrile illness after filming a documentary about vampire bats in Guatemala. Patients developed symptoms after travelling to Australia, where they presented for medical care.
\end{abstract}

Keywords: histoplasmosis; travel; outbreak; Guatemala

\section{Case Report}

From 24 March to 4 April 2018, 12 television crew members filmed a nature documentary about vampire bats in the Cueva de Juan Flores, Petén Department, Guatemala. All film crew members received general pre-travel assessment and counselling, including recommended pre-travel vaccinations, including influenza, hepatitis $\mathrm{A}$, typhoid and rabies vaccination. Although crew members were encouraged to wear a mask as a general safety measure, they were periodically removed due to perceived discomfort in the humid conditions of the cave.

The television crew then travelled to Australia, where some members flew to Melbourne to begin filming another nature documentary, while the others remained in Sydney. Two patients presented to our health service (both camera operators), while the other three presented to local health services in Sydney, Australia (an audio engineer, television producer and host). The two patients who presented to our health service were both males, aged 33 (patient 1) and 54 (patient 2), with no significant past medical history. A written informed consent for publication was obtained from both patients. Their symptoms presented over the course of $24 \mathrm{~h}$, including severe fatigue, neck and shoulder pain, headache, fevers, chills and cough. Symptom onset in both patients was 8 days after completion of filming.

On examination, both patients were febrile between $39-41{ }^{\circ} \mathrm{C}$ and haemodynamically stable. Oxygen saturation was $\geq 97 \%$ in both patients. Physical examination of both patients was otherwise unrevealing, with a clear chest on auscultation and no lymphadenopathy or organomegaly. Full blood examination was within normal limits for both patients, with frequent atypical and reactive lymphocytes on blood film. Both patients had normal renal and hepatic function with moderately elevated C-reactive protein. Both patients also received a chest x-ray, which was unremarkable in patient 1 . The chest $x$-ray of patient 2 showed mild patchy reticular markings, but was otherwise normal. Additional investigations for influenza, malaria, typhoid, leptospirosis, rickettsia, arboviruses and atypical pneumonia were negative. 
Given the exposure of both patients to caves in Central America, histoplasmosis serology was performed via immunodiffusion (Westmead Hospital, Sydney, Australia) and a urinary antigen (by EIA) was sent to Indianapolis, Indiana (MiraVista Diagnostics). Patient 2 provided a sputum sample, which was sent to Westmead Hospital, Sydney for prolonged incubation fungal culture.

Both patients were monitored for $72 \mathrm{~h}$, by which point symptoms had significantly improved without antifungal therapy, and treatment was supportive, in concordance with IDSA guidelines [1]. Subsequent correspondence with both patients confirmed recovery by 4 weeks. Clinical information regarding the three unwell film crew members who travelled to Sydney was unavailable to our unit.

Histoplasmosis serology was initially negative by immunodiffusion in both patients (Westmead Hospital, Sydney, Australia). Histoplasma urinary antigen (MiraVista, Indianapolis, IN, USA) was detected in both patients, with a turn-around time of 13 days. The diagnosis was subsequently confirmed serologically in patient 1 , who returned to his primary healthcare physician in the United States one week after discharge, where complement fixation demonstrated a 1:16 titre to yeast-phase antibody, and immunodiffusion detected a positive M band (Quest Diagnostics, West Hills, CA, USA). In patient 2, the diagnosis was confirmed in sputum, which was culture-positive after 4 weeks.

\section{Discussion}

The key challenge for clinicians reviewing travellers from regions endemic for $H$. capsulatum is the non-specific presentation of patients with acute pulmonary histoplasmosis (APH), which may mimic a number of bacterial and viral infections seen in returned travellers. A unique form of epidemiological evidence available to clinicians in this case included video footage viewed by the treating team, which confirmed hundreds of bats flying overhead in a swarming fashion, probably disturbed by the human activity and exposure to artificial light. Bat guano was also recorded on film to be falling directly onto our patients within the caving system (Figure 1, recorded by patient 1 ).

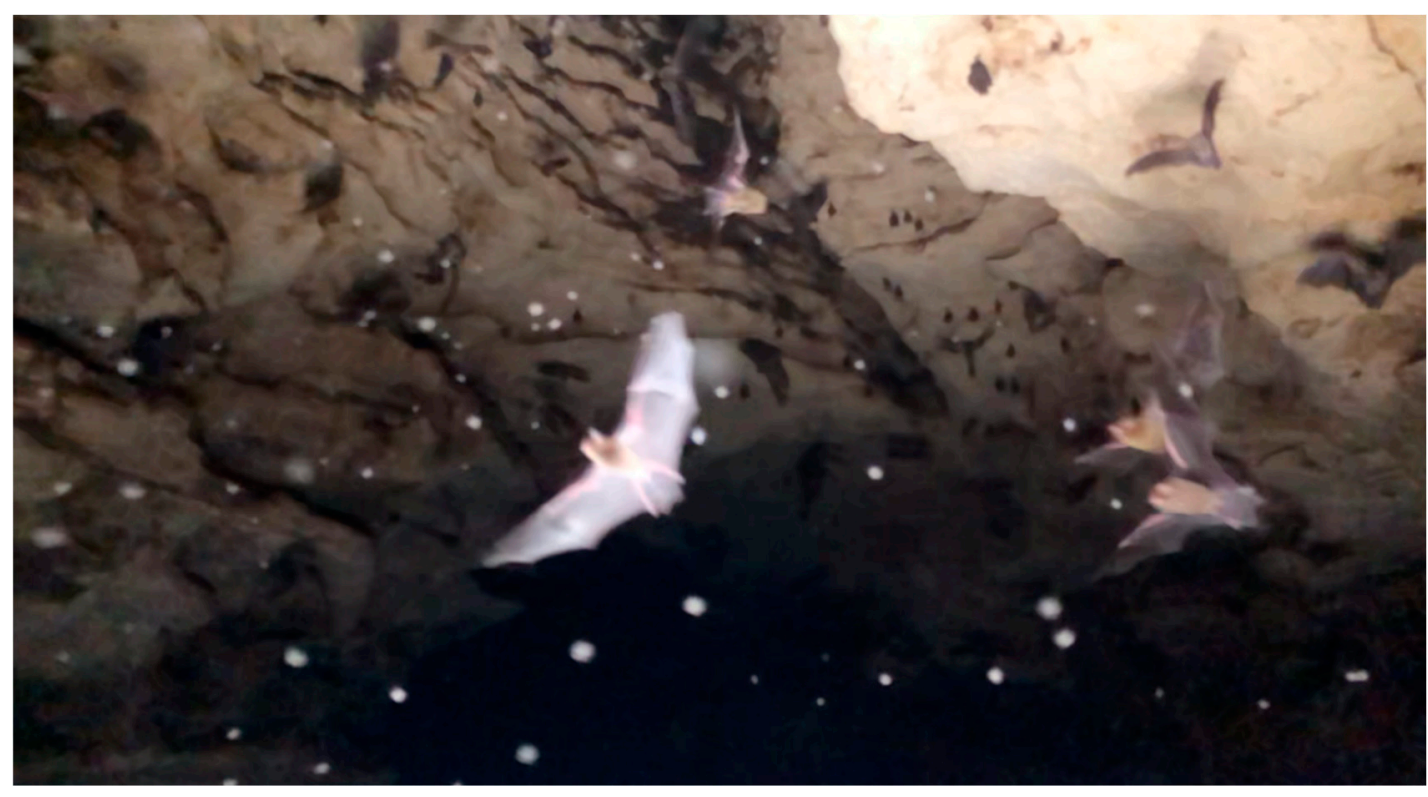

Figure 1. Image of bats filmed by patient 1 (particulate matter seen falling from above in foreground).

An increasing number of clustered cases in travellers have been reported in the literature, largely due to a rise in international travel and increasing rates of ecotourism (Table 1) [2-8]. The generally high attack rate is indicative of the large inoculum of infection, as exposure to caves and bat guano remains a key feature in the majority of previous reports. Diagnostic testing and treatment in these published reports also varies widely. Despite endemnicity in Australia, the unavailability of histoplasmosis urinary antigen continues to impair rapid diagnostic testing, particularly in acute cases, prior to seroconversion and culture positivity. 
Table 1. Outbreaks of acute pulmonary histoplasmosis in travellers from South and Central America.

\begin{tabular}{|c|c|c|c|c|c|}
\hline Location & Year & Population/Activity & Attack Rate, \% & Diagnosis & Treatment (\%, Primary Indication) \\
\hline Ecuador (2) & 1999 & $\begin{array}{l}\text { US high school students } \\
\text { cave exploring }\end{array}$ & $11 / 17(65 \%)$ & $\begin{array}{l}\text { Urine Ag } 0 / 2(0 \%) \\
\text { Serology: } 4 / 7(57 \%)\end{array}$ & $3 / 17$ ( $18 \%$, prolonged symptoms) \\
\hline Belize (4) & 2002 & $\begin{array}{l}\text { Canadian high school } \\
\text { students cave exploring }\end{array}$ & $14 / 15(93 \%)$ & $\begin{array}{l}\text { Urine Ag } 5 / 7(71 \%) \\
\text { Serology: } 3 / 15(20 \%)\end{array}$ & $1 / 15$ ( $7 \%$, prolonged symptoms) \\
\hline El Salvador (6) & 2008 & $\begin{array}{l}\text { US missionaries renovating } \\
\text { a church }\end{array}$ & $20 / 33(61 \%)$ & $\begin{array}{l}\text { Antigen (serum/urine) } \\
7 / 20(35 \%)\end{array}$ & Not reported \\
\hline Ecuador (7) & 2012 & $\begin{array}{l}\text { Polish tourists (organised tour) } \\
\text { cave exploring }\end{array}$ & $4 / 4(100 \%)$ & Serology: 4/4 (100\%) & $2 / 4$ (50\%, prolonged symptoms) \\
\hline Brazil (8) & 2013 & $\begin{array}{l}\text { Scientists, researching } \\
\text { histoplasmosis in caves }\end{array}$ & $4 / 8(50 \%)$ & $\begin{array}{l}\text { Serology } 0 / 4(0 \%) \\
\text { Sputum cytology, } \\
\text { culture } 4 / 4(100 \%)\end{array}$ & $2 / 4$ (50\%, prolonged symptoms) \\
\hline
\end{tabular}

Our cases demonstrate the utility and feasibility of performing urinary antigen testing, which is reportedly the most sensitive test to diagnose APH [9]. Although APH is cross-reactive with other endemic mycoses, this is not a consideration in cases acquired in Australia, further supporting previous calls for its introduction in a national reference laboratory [10]. When used alone to diagnose APH, urinary antigen is limited by its poor overall performance [11]. However, a more recently developed EIA (MiraVista Diagnostics) measures both immunoglobulin G (IgG) and IgM, reporting a sensitivity of 96.3\% for APH, when combining both antigen and antibody assays [11]. As demonstrated in the case of patient 1 , convalescent serology should be repeated after several weeks, if negative during initial testing.

The severity of illness in our patients was mild, requiring a short period of hospitalisation for observation, diagnostic work-up and supportive management. It is difficult to quantify the inoculum of exposure, as masks were intermittently removed during filming. Patients were educated on the need for compliance with personal-protective equipment, and also counselled regarding the risk of reactivation in the event of immunosuppression. Both of our patients travelled overseas soon after their hospitalisation. These cases continue to highlight the dynamic interaction between adventure tourism and human curiosity, trans-continental travel and the evolving human-animal-ecosystem interface.

Author Contributions: Writing—original draft preparation, S.M. Writing—review and editing, S.M.; A.C. Supervision, J.D.

Funding: This research received no external funding.

Conflicts of Interest: The authors declare no conflict of interest.

\section{References}

1. Wheat, L.J.; Freifeld, A.G.; Kleiman, M.B.; Baddley, J.W.; McKinsey, D.S.; Loyd, J.E.; Kauffman, C.A. Clinical practice guidelines for the management of patients with histoplasmosis: 2007 update by the Infectious Diseases Society of America. Clin. Infect. Dis. 2007, 45, 807-825. [CrossRef] [PubMed]

2. Valdez, H.; Salata, R.A. Bat-associated histoplasmosis in returning travelers: Case presentation and description of a cluster. J. Travel Med. 1999, 6, 258-260. [CrossRef] [PubMed]

3. Weinberg, M.; Weeks, J.; Lance-Parker, S.; Traeger, M.; Wiersma, S.; Phan, Q.; Dennison, D.; MacDonald, P.; Lindsley, M.; Guarner, J. Severe histoplasmosis in travelers to Nicaragua. Emerg. Infect. Dis. 2003, 9, 1322. [CrossRef] [PubMed]

4. Buxton, J.A.; Dawar, M.; Wheat, L.J.; Black, W.A.; Ames, N.G.; Mugford, M.; Patrick, D.M. Outbreak of histoplasmosis in a school party that visited a cave in Belize: Role of antigen testing in diagnosis. J. Travel Med. 2002, 9, 48-50. [CrossRef] [PubMed]

5. Nygård, K.; Brantsaeter, A.; Feruglio, S.; Ravn, J.; Dotevall, L.; Hasle, G.; Myrvang, B. Histoplasmosis among travellers to Central America. J. Nor. Med. Assoc. 2006, 126, 2838-2842. 
6. Centers for Disease Control and Prevention (CDC). Outbreak of histoplasmosis among travelers returning from El Salvador-Pennsylvania and Virginia, 2008. Morb. Mortal Wkly. Rep. 2008, 57, 1349-1353.

7. Kajfasz, P.; Basiak, W. Outbreak of pulmonary histoplasmosis involving a group of four Polish travellers returning from Ecuador. Int. Marit. Health 2012, 63, 59-62. [PubMed]

8. Rocha-silva, F.; Figueiredo, S.M.; Silveira, T.T.; Assunção, C.B.; Campolina, S.S.; Pena-barbosa, J.P.; Rotondo, A.; Caligiorne, R.B. Histoplasmosis outbreak in Tamboril cave-Minas Gerais state, Brazil. Med. Mycol. 2014, 4, 1-4. [CrossRef] [PubMed]

9. Wheat, L.J. Approach to the diagnosis of the endemic mycoses. Clin. Chest Med. 2009, 30, 379. [CrossRef] [PubMed]

10. McLeod, D.S.; Mortimer, R.H.; Perry-Keene, D.A.; McBride, W.J.; Coulter, C.; Robson, J.M. Histoplasmosis in Australia: Report of 16 cases and literature review. Medicine 2011, 90, 61-68. [CrossRef] [PubMed]

11. Richer, S.M.; Smedema, M.L.; Durkin, M.M.; Herman, K.M.; Hage, C.A.; Fuller, D.; Wheat, L.J. Improved diagnosis of acute pulmonary histoplasmosis by combining antigen and antibody detection. Clin. Infect. Dis. 2016, 62, 896-902. [CrossRef] [PubMed]

(C) 2019 by the authors. Licensee MDPI, Basel, Switzerland. This article is an open access article distributed under the terms and conditions of the Creative Commons Attribution (CC BY) license (http:/ / creativecommons.org/licenses/by/4.0/). 